doi: 10.32620/oikit.2021.91.09

УДК 538.95

О. О. Баранов

\title{
Теоретична модель формування двовимірних наноструктур вертикального графену під дісю плазми
}

\author{
Національний аерокосмічний університет ім. М.Є. Жуковського \\ "Харківський авіаційний інститут»
}

\begin{abstract}
Вертикально орієнтовані графенові наноструктури вирощують уже більше десяти років, але механізми їх формування і на теперішній час $€$ невизначеними. Запропоновано багатофракторну модель, яка перевірена шляхом порівняння з експериментальними даними і описує процеси зростання структури вертикального графену у плазмовому середовищі. Досліджено роль хімічних і фрізичних процесів, які неможливо безпосередньо охарактеризувати за допомогою доступних експериментальних методів, наприклад поверхневу дифузію адсорбованих атомів і радикалів під дією іонів. Бомбардування іонами $€$ ключовим чинником, що значно прискорює швидкість зростання шляхом утворення поверхневих десектів і, отже, збільшення енергії поверхневої адсорбції. Вуглеводневі радикали, що утворюються на підкладці внаслідок бомбардування, дифундують до нанопластівців і служать основним джерелом матеріалу для побудови нанопластівців. Таким чином, провідна роль у процесі формування вертикального графену належить поверхневій дифузії, а не прямому осадженню з газової фрази. Температура зразка також $є$ важливим параметром, який таким чином впливає на процес росту: при низькій температурі адсорбція 3 газової фази $є$ більш інтенсивною, проте процеси дифузії сповільнюються; підвищені температури діють протилежно. Поверхнева щільність графенових нанопластівців, яку можна контролювати на стадії зародження, сильно впливає на висоту пластівців через перерозподіл потоків іонів під час зростання: у міру зростання пластівців густина струму іонів до бічного краю пластівця зменшується, а на верхньому краї збільшується. Цей процес призводить до зменшення густини іонного струму на бічний край нанопластівця, i, як наслідок, до змінення залежності довжини пластівця графрену у часі: від кривої із насиченням або квазілінійною залежністю від часу до параболічної залежності. Припущення про поверхневу дифузію вуглеводневих радикалів як про домінуючий механізм зростання узгоджується 3 існуючими експериментальними даними; наведені результати підтверджують фізичну модель, а також привносять більш глибоке розуміння фізики зростання вертикального графену.
\end{abstract}

Ключові слова: нанотехнологія, плазма, вертикальний графен, методи зростання наноструктур.

\section{Вступ}

Вуглецеві наноструктури різної вимірності (нанокрапки, нанокластери, нанотрубки, нанодроти, нанопластівці, складні структури, що $є$ поєднанням указаних вище) викликають значний інтерес дослідників і виробників через їх видатні фрізичні, хімічні та механічні властивості при порівнянні 3 мікро- та макроструктурами [1,2]. Вертикально орієнтовані нанофракції графенових і вуглецевих структур («вертикальний графен») [3,4] - це двовимірні наноструктури (2D), які утворюють матеріал зі значним співвідношенням поверхні до об'єму $[5,6]$, що робить їх відмінними кандидатами як компонентами для польових транзисторів $[7,8]$, нанофлюїдних застосувань $[9,10]$, суперконденсаторів $[11,12]$, космічної технології [13] і поглиначів електромагнітних хвиль [14], фоотоелектричних пристроїв [15] та пристроїв на основі автоелектронної емісії [16]. 
Для синтезу вуглецевих наноструктур плазмові методи є основними; вони основані на використанні плазми, яка генерується шляхом застосування мікрохвильової [17] та радіочастотної енергії [18-20], або постійного струму [21]. Процес проходить в об'ємі вакуумної камери, яка містить газ із вуглецевим компонентом, як правило, $\mathrm{CH}_{4}$ або $\mathrm{C}_{2} \mathrm{H}_{2}[22,23]$, оскільки вважають, що радикали $\mathrm{CH}_{x}(x=1 \ldots 3) \in$ будівельними блоками для синтезу. Додатково до камери вводять $\mathrm{H}_{2}, \mathrm{~N}_{2}$, Ar під загальним тиском газу в камері від 1 до $10^{5}$ Па; можливо використання каталізаторів, але їх наявність необов'язкова [24, 25].

Серед основних технологічних засобів керування ростом вуглецевих наноструктур $€$ тиск газу, співвідношення вуглеводневого газу до травника $\alpha-C$ i температура підкладки [26]. У той же час природа матеріалу підкладки може незначно впливати на хімічний склад та морфологію [27]. У ряді експериментів спостерігалася лінійна залежність довжини графену від часу, що передбачає провідну роль прямого потоку радикалів $\mathrm{CH}_{\mathrm{X}} 3$ плазми $[21,28]$; в інших звітах наведено експериментальні докази того, що саме поверхнева дифузія $\mathrm{CHx} \epsilon$ домінуючим механізмом зростання [29]. Більше того, навіть походження основних реагентів для створення вертикального графену $\epsilon$ причиною для дискусії, внаслідок якої виникають два суперечливих механізми зростання: або безпосередньо з газоплазмової фази, або через поверхневу дифузію як шлях доставки реагентів із поверхні підкладки до краю графену [30, 31]. Отже, плазма $€$ універсальним інструментом у технології отримання оксидних і вуглецевих наноструктур, але розвиток плазмових методів стримується недостатньо розвиненою теоретичною базою.

\section{1. Теоретична модель}

Модель описує «вертикальну» стадію зростання графену, тобто взаємодію графенового пластівця 3 поверхнею зразка-підкладки, до якої прикріплено цей пластівець і яка $€$ джерелом атомів вуглецю, тобто будівельного матеріалу для графену. Таким чином, у моделі не розглядається початкова стадія фрормування пластівця, протягом якої шар графіту певної структури зростав паралельно поверхні підкладки в плівці аморфоподібного вуглецю [32]. Основними об'єктами, що взаємодіють у моделі, є молекули метану $\mathrm{CH}_{4}$, водню $\mathrm{H}_{2}$, вуглеводневі радикали $\mathrm{CHx}(\mathrm{x}=1,2,3)$, атоми вуглецю $\mathrm{C}$ $\left(\mathrm{x}=0\right.$ у формулі $\mathrm{CHx}$ ), втоми водню $\mathrm{H}$, іони водню $\mathrm{H}_{2}{ }^{+}$, поверхня шару аморфного вуглецю $\mathrm{C}_{(\alpha)}$, бічна поверхня $\mathrm{G}_{(\mathrm{S})}$ графенового пластівця, гострий край $\mathrm{G}_{(\mathrm{E})}$ пластівця, а також атоми вуглецю $\mathrm{C}_{\mathrm{G}}$, прикріплені до краю пластівця.

Припускається, що кількість радикалів, які утворюються на поверхні, значно перевищує кількість радикалів, що утворюються в плазмі і осідають безпосередньо на краях. Схема типового процесу плазмового росту вертикально орієнтованих пластівців графену показана на рис. 1.

Густини $n_{C H 4}$ i $n_{H 2}$ молекул $\mathrm{CH}_{4}$ і $\mathrm{H}_{2}$ на поверхні підкладки $(z=0)$ виражаються у формі ізотерми адсорбції Ленгмюра за припущенням малої щільності $\left(n_{\mathrm{CH} 4} / n_{\mathrm{O}}<1\right.$ і $\left.n_{\mathrm{H} 2} / n_{\mathrm{O}}<1\right)$ [33]:

$$
\frac{n_{\mathrm{CH}_{4}}}{n_{0}}=\frac{P_{\mathrm{CH}_{4}}}{P_{\mathrm{OCH}_{4}}+P_{\mathrm{CH}_{4}}}, \quad \frac{n_{\mathrm{H}_{2}}}{n_{0}}=\frac{P_{H_{2}}}{P_{0 H_{2}}+P_{H_{2}}},
$$

де $P_{C H 4}$ і $P_{H 2}-$ парціальний тиск газів-попередників, Па; $P_{O C H 4}$ і $P_{O H 2}-$ константи, які не залежать від тиску $P_{C H 4}$ і $P_{H 2} ; n_{O}-$ поверхнева щільність атомів вуглецю (щільність вузлів адсорбції). Константи знаходять так: 


$$
\begin{gathered}
P_{0 C H_{4}}=\left(\frac{M_{C}+4 M_{H}}{2 \pi h^{2}}\right)^{3 / 2}\left(k_{B} T_{S}\right)^{5 / 2} \exp \left(-\frac{e \varepsilon_{\alpha C H_{4}}(\alpha)}{k_{B} T_{S}}\right), \\
P_{0 H_{2}}=\left(\frac{M_{H}}{\pi h^{2}}\right)^{3 / 2}\left(k_{B} T_{S}\right)^{5 / 2} \exp \left(-\frac{e \varepsilon_{\alpha H_{2}(\alpha)}}{k_{B} T_{S}}\right),
\end{gathered}
$$

де $M_{C}$ i $M_{H}$-- маси атомів вуглецю та водню, кг; $k_{B}$ - стала Больцмана; $e$ - заряд електрона; $T_{s}$ - температура зразка; $\varepsilon_{a+2(\alpha)}$ та $\varepsilon_{a C H 4(\alpha)}$ - енергії адсорбції молекул водню та вуглеводнів.

Парціальний тиск газів-попередників та $\alpha$-травника виражається як

$$
P_{\mathrm{CH}_{4}}=\frac{\varphi_{\mathrm{CH}_{4}}}{\varphi_{0 \mathrm{CH}}+\varphi_{\mathrm{CH}_{4}}} P, \quad P_{\mathrm{H}_{2}}=\frac{\varphi_{\mathrm{H}_{2}}}{\varphi_{0 \mathrm{H}_{2}}+\varphi_{\mathrm{H}_{2}}} P,
$$

де $\phi_{C H 4}$ та $\phi_{H 2}$ - потоки газу-попередника та травника $\alpha-C$, сксм; $P$ - загальний тиск газу в камері, Па (вважається, що в реакторі відсутні інші гази).

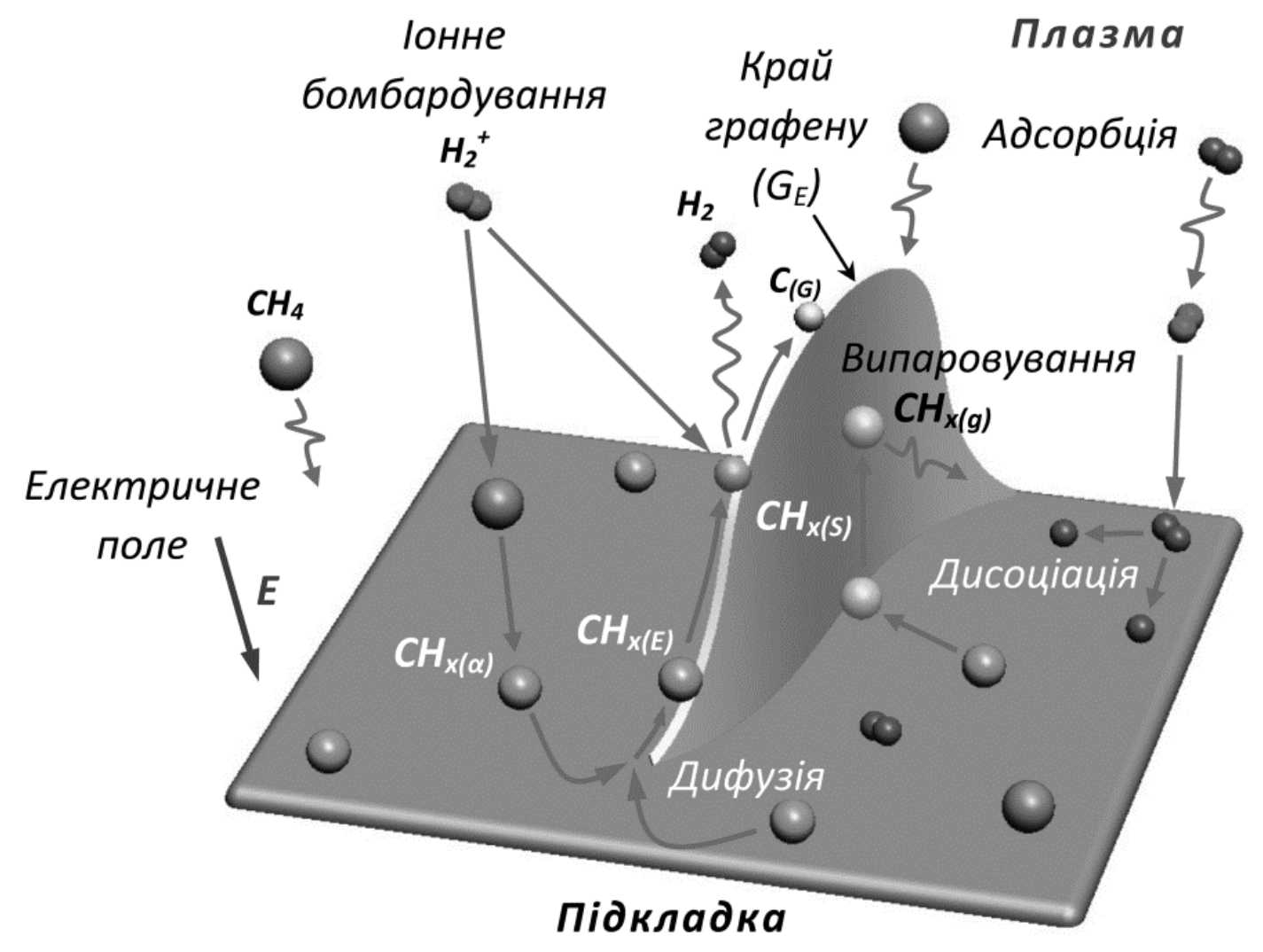

Рис. 1. Схема зростання вертикального графену під дією плазми

Енергія адсорбції молекули метану змінюється $3 \varepsilon_{a C H 4(\alpha)}$ на $\varepsilon_{\mathrm{aCHx}(\alpha)}$ після теплової або індукованої іонами дисоціації, внаслідок якої молекула $\mathrm{CH}_{4}$ поступово перетворюється на з'єднання $\mathrm{CH}_{\mathrm{x}}$, де $x=3,2,1,0$.

Поверхнева густина радикалів $n_{\mathrm{CHx}}$ залежить від швидкості конверсії адсорбованого газу-попередника та травника $\alpha-C$ на поверхні. Для опису процесу генерації радикалів розглядається баланс між процесами генерації 
радикалів і втратою адсорбованих молекул; темпи змінення густини описуються рівняннями:

$$
\begin{aligned}
\frac{d n_{H_{2}}}{d t}=2 n_{H} \frac{n_{H}}{n_{0}} v_{0} \exp \left(-\frac{e \varepsilon_{a H(\alpha)}}{k_{B} T_{s}}\right)-n_{H_{2}}\left[a_{0}^{2} \frac{j_{i}}{e} \frac{n_{H_{2}}}{n_{0}}+v_{0} \exp \left(-\frac{e \varepsilon_{d H_{2}}}{k_{B} T_{s}}\right)\right], \\
\frac{d n_{C H_{4}}}{d t}=n_{H} \frac{n_{C H x}}{n_{0}} v_{0}\left[\exp \left(-\frac{e \varepsilon_{a H(\alpha)}}{k_{B} T_{s}}\right)+\exp \left(-\frac{e \varepsilon_{a} C H x(\alpha)}{k_{B} T_{s}}\right)\right]- \\
-n_{C H_{4}}\left[a_{0}^{2} \frac{j_{i}}{e} \frac{n_{C H_{4}}}{n_{0}}+v_{0} \exp \left(-\frac{e \varepsilon_{d i s C H_{4}}}{k_{B} T_{s}}\right)\right]
\end{aligned}
$$

де $v_{0}$ - частота коливань кристалічної ґратки, $v_{0}=2 k_{B} T_{s} / h$ [34], $h$ - стала Планка; $j_{0}$ - середня густина іонного струму з плазми на зразок-підкладку; $n_{H 2}$ та $n_{C H 4}-$ поверхневі густини адсорбованого водню та вуглеводневого газу; $\varepsilon_{d H 2}$ та $\varepsilon_{d C H 4}-$ енергії дисоціації адсорбованого водню та вуглеводневого газу; $n_{H}$ та $n_{C H x}-$ поверхневі густини атомів водню та вуглеводневих радикалів; $\varepsilon_{a H(\alpha)}$ та $\varepsilon_{a C H x(\alpha)}-$ енергії активації дифузії атомів водню та вуглеводневих радикалів.

Перший доданок у рівняннях (5)-(9) описує зменшення густини адсорбованих молекул внаслідок рекомбінації 3 атомами водню, адсорбованими на поверхні (які утворюються після дисоціації молекул, що спричинена іонним бомбардуванням і тепловими процесами); другий доданок зростання концентрації внаслідок дисоціації, спричиненої бомбардуванням іонами $\left(j_{i}\right)$ та температурою $\left(T_{s}\right)$. Третій доданок у рівняннях (6)-(9) також описує збільшення густини за рахунок рекомбінації атомів і радикалів.

У формулах (6)-(9) чинник виду $\exp \left(-e \varepsilon_{(1)} / k_{B} T_{s}\right)$ описує ймовірність подолання енергетичного бар'єру $\varepsilon_{(1)}$ при середній енергії в системі $k_{B} T_{s}$; чинник виду $n_{(\eta)} / n_{0}$ описує ймовірність наявності частки $i$ в адсорбційному вузлі $\left(n_{0}-\right.$ густина адсорбційних вузлів на поверхні, м $^{-2}$ ).

Розглянуто два шляхи впливу іонного бомбардування на процеси зростання наноструктур. По-перше, це змінення енергії $\varepsilon_{(\text {() }}$ активації процесів, тобто вона може збільшуватися або зменшуватися завдяки активації («функціоналізації») поверхні. По-друге, завдяки балістичним процесам - коли енергія, отримана часткою при взаємодії з іоном плазми, призводить до дисоціації цієї частки, внаслідок чого на одиницю зменшується число $x$ у фрормулі $\mathrm{CH}_{\mathrm{x}}$, і відщеплений атом водню рухається вздовж поверхні з певною швидкістю, поступово втрачаючи енергію внаслідок взаємодії з поверхневими атомами кристалічної ґратки.

Для усталеного режиму похідні дорівнюють нулю, а наведена вище система рівнянь (4), (5) дозволяє визначити стаціонарну густина різних компонентів на поверхні зразка-підкладки:

$$
n_{H_{2}}\left[a_{0}^{2} \frac{j_{i}}{e} \frac{n_{H_{2}}}{n_{0}}+v_{0} \exp \left(-\frac{e \varepsilon_{d H_{2}}}{k_{B} T_{s}}\right)\right]=2 n_{H} \frac{n_{H}}{n_{0}} v_{0} \exp \left(-\frac{e \varepsilon_{a H(\alpha)}}{k_{B} T_{s}}\right),
$$




$$
\begin{aligned}
& n_{C H_{4}}\left[a_{0}^{2} \frac{j_{i}}{e} \frac{n_{C H_{4}}}{n_{0}}+v_{0} \exp \left(-\frac{e \varepsilon_{d i s C H_{4}}}{k_{B} T_{s}}\right)\right]= \\
& =n_{H} \frac{n_{C H x}}{n_{0}} v_{0}\left[\exp \left(-\frac{e \varepsilon_{a H(\alpha)}}{k_{B} T_{s}}\right)+\exp \left(-\frac{e \varepsilon_{a C H x}(\alpha)}{k_{B} T_{s}}\right)\right]
\end{aligned}
$$
молекул:

Із цих рівнянь визначається стаціонарна поверхнева густина атомів і

$$
\begin{aligned}
& n_{H}=n_{0}\left(\frac{P_{H_{2}}}{P_{0 H_{2}}+P_{H_{2}}}\right)^{1 / 2}\left[\begin{array}{l}
\frac{j_{i} a_{0}^{2}}{e v_{0}} \frac{P_{H_{2}}}{P_{0 H_{2}}+P_{H_{2}}} \exp \left(\frac{e \varepsilon_{a H(\alpha)}}{k_{B} T_{s}}\right) \\
+\exp \left(-\frac{e\left(\varepsilon_{d H_{2}}-\varepsilon_{a H(\alpha)}\right)}{k_{B} T_{s}}\right)
\end{array}\right]^{1 / 2}, \\
& \frac{n_{C H x}}{n_{0}}=\frac{\frac{P_{C_{4}}}{P_{0 H_{4}}+P_{C H_{4}}}\left(\frac{P_{0 H_{2}}+P_{H_{2}}}{P_{H_{2}}}\right)^{1 / 2}\left(\frac{j_{i} a_{0}^{2}}{e v_{0}} \frac{P_{C H_{4}}}{P_{0 C H_{4}}+P_{C H_{4}}}+\exp \left(-\frac{\left.e \varepsilon_{d C H_{4}}\right)}{k_{B} T_{s}}\right)\right)}{\left[\begin{array}{l}
\frac{j_{i} a_{0}^{2}}{e v_{0}} \frac{P_{H_{2}}}{P_{0 H_{2}}+P_{H_{2}}} \exp \left(\frac{e \varepsilon_{a H}(\alpha)}{k_{B} T_{s}}\right)+ \\
+\exp \left(-\frac{e\left(\varepsilon_{d H_{2}}+\varepsilon_{a H(\alpha)}\right)}{k_{B} T_{s}}\right)
\end{array}\right]^{1 / 2}\left(1+\exp \left(-\frac{\left.e\left(\varepsilon_{a C H_{x}(\alpha)}-\varepsilon_{a H(\alpha)}\right)\right)}{k_{B} T_{s}}\right)\right)} .
\end{aligned}
$$

Ця система описує густину вуглеводневих радикалів і атомів вуглецю як функцію тиску газу-попередника, тиску газу-травника шару $\alpha-C$, температури зразка та густини струму іонів на поверхню. Таким чином, густина атомів і радикалів СНх визначається рівновагою між процесами дисоціації молекул в умовах бомбардування іонами та рекомбінацією на поверхні підкладки. Крім того, енергії адсорбції залежать від стану поверхні, яка може бути насичена дефектами внаслідок бомбардування іонами. При цьому слід наголосити, що концентрації метану та водню $є$ незмінними і визначаються ізотермою адсорбції Ленгмюра.

Радикали на шарі аморфоподібного вуглецю $\mathrm{C}_{(\alpha)}$ також можуть дисоціювати внаслідок іонного бомбардування, а виділений атом вуглецю може бути прикріплений до шару $\mathrm{C}_{(\alpha)}$. Остання реакція приводить до зростання шару $\mathrm{C}_{(\alpha)}$ і тут не розглядається. Радикал $\mathrm{CH}_{\mathrm{x}}$ може дифундувати вздовж шару $\mathrm{C}_{(\alpha)} \mathrm{i}$ може адсорбуватися на стороні або краю пластівця під час дифузії, на цьому

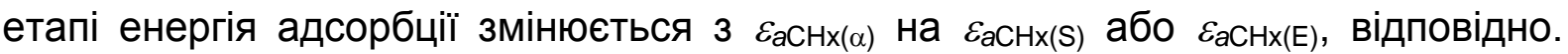
Оскільки бічну поверхню $S$ можна вважати ідеальною, енергія $\varepsilon_{a \mathrm{CH}}(\mathrm{S})$ досить мала $\left(\varepsilon_{a \mathrm{CH}}(\mathrm{S}) \rightarrow 0\right)$, тому атом вуглецю швидко випаровується. Якщо ж атом вуглецю адсорбується на високодефектному краї $E$ пластівця, енергія адсорбції збільшується $\left(\varepsilon_{a \mathrm{CHx}(\alpha)} \rightarrow \varepsilon_{a \mathrm{CHx}(\mathrm{E})}\right)$, і радикал може дифундувати по краю досить довго з низькою ймовірністю випаровування або переходу до бічної поверхні $S$ пластівця $\left(\varepsilon_{a \mathrm{CHx}(\mathrm{G})} \gg \varepsilon_{a \mathrm{CH}(\mathrm{S})}\right)$ [35]. Під час дифрузійного руху вздовж краю $E$ радикал може також взаємодіяти з іоном плазми, в результаті чого він дисоціює 
через енергію, отриману від іона. Ця подія приводить до вивільнення атома вуглецю, який безпосередньо приєднується до краю $E$, тим самим забезпечуючи ріст графенового пластівця. Ймовірність включення атома вуглецю в кристалічну ґратку пластівця описується виграшем енергії з урахуванням температури підкладки.

Швидкість зростання пластівця при іонному бомбардуванні краю $E$ пластівця з координатою $z$ дорівнює [36]:

$$
\begin{aligned}
& V_{v g-i o n}(z)=\frac{n_{C H}(z)}{n_{0}} \frac{j_{i R}}{e} a_{0}^{3} \exp \left(-\frac{e\left(\varepsilon_{x-d i s}-\varepsilon_{x i}\right)}{k_{B} T_{s}}\right)= \\
& =\frac{n_{C H}(z)}{n_{0}} \frac{j_{i R}}{e} a_{0}^{3} \exp \left(-\frac{e \varepsilon_{x-d i s}\left(1-\alpha_{\varepsilon}\right)}{k_{B} T_{s}}\right),
\end{aligned}
$$

де $n_{C H}(z)$ - густина радикалів $\mathrm{CH}_{\mathrm{x}}$ на краю $E$ з координатою $z$; $a_{0}$ - параметр ґратки пластівця, м; $n_{0}$ - густина атомів вуглецю на краю (густина вузлів адсорбції), $n_{0}=a_{0}^{-2} ; \exp \left(-e \varepsilon_{x}\right.$-dis $\left./ k_{B} T_{s}\right)$ - ймовірність дисоціації радикала $\mathrm{CH}_{\mathrm{x}}$ шляхом подолання потенційного бар'єру $\varepsilon_{x \text {-dis }}(\mathrm{eB})$ при температурі підкладки $T_{s}, \mathrm{~K} ; k_{B}$ - постійна Больцмана; $e$ - заряд електрона; $a_{0}^{3}$ - об'єм, який утворюється за умови, що відбулася реакція дисоціації радикала $\mathrm{CH}_{\mathrm{x}} 3$ подальшим утворенням атома вуглецю; $j_{i R}$ - густина іонного струму до краю $E$, $\mathrm{A} / \mathrm{M}^{2} ; j_{i R} / e-$ потік іонів; $n_{C H} / n_{0}-$ ймовірність знайти радикал $\mathrm{CH}$ в адсорбційному вузлі під час іонного бомбардування; $\left.n_{C H} / n_{0}\left(j_{i R} / e\right) \exp \left[-e\left(\varepsilon_{x-d i s}-\varepsilon_{x i}\right) / k_{B} T_{s}\right)\right]$ - частота на одиницю площі дисоціації радикалів $\mathrm{CH}_{\mathrm{x}}$ у вузлі за рахунок енергії $\varepsilon_{x i}$, отриманої при взаємодії 3 іоном, причому $\varepsilon_{x \text {-dis }} \geq \varepsilon_{x i}$ (випадок, коли $\varepsilon_{x \text {-dis }}<\varepsilon_{x i}$, розглядається як розпилення), $\alpha_{\varepsilon} \in$ відношенням $\varepsilon_{x i}$ до $\varepsilon_{x}$-dis. становить:

Швидкість розпилення іонів для краю $E$ при будь-якій координаті $z$

$$
V_{v g-s p u t}(z)=Y \frac{j_{i R}}{e} a_{0}^{3}
$$

де $Y a_{0}^{3}$ - об'єм, видалений за умови, що на вуглецевий шар впливає потік іонів

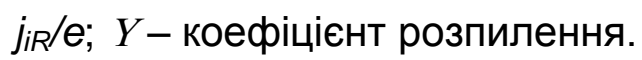

Тоді результуюча швидкість зростання для краю $E$ з координатою $Z$ дорівнює:

$$
\begin{aligned}
& V_{v g-W}(z)=\frac{d W_{v g}(z, t)}{d t}=V_{v g-i o n}(z)-V_{v g-s p u t}(z)= \\
& =\frac{n_{C H x}(z)}{n_{0}} \frac{j_{i R}}{e} a_{0}^{3} \exp \left(-\frac{e \varepsilon_{x-d i s}\left(1-\alpha_{\varepsilon}\right)}{k_{B} T_{s}}\right)-Y \frac{j_{i R}}{e} a_{0}^{3},
\end{aligned}
$$

де $W_{v g}$ - напівширина пластівця вертикального графену.

Розподіл $n_{C H}(z)$ визначається вирішенням такого рівняння, яке описує стаціонарний режим дифузії вуглеводневих радикалів з поверхні підкладки:

$$
D_{C H} \frac{\partial^{2} n_{C H x}}{\partial z^{2}}=-\frac{n_{C H x}(z)}{n_{0}} \frac{j_{i R}}{e} \exp \left(-\frac{e \varepsilon_{x-d i s}\left(1-\alpha_{\varepsilon}\right)}{k_{B} T_{s}}\right),
$$

де коефіцієнт дифузії 


$$
D_{C H x}=D_{0 C H x} \exp \left(-\frac{e \varepsilon_{\alpha C H x}(E)}{k_{B} T_{S}}\right),
$$

де $\varepsilon_{a C H x(E)}$ - енергія активації, еB; $D_{0 C H x}$ - коефіцієнт, що залежить від температури:

$$
D_{0 C H x}=\frac{v_{0} a_{0}^{2}}{2}=\frac{k_{B} T_{S}}{h} a_{0}^{2},
$$

де $v_{0}$ - частота коливань ґратки, $h$ - стала Планка.

У моделі використовують припущення, що на стадії вертикального зростання пластівця електричне поле відіграє важливу роль фокусування потоку іонів з плазми до краю $E$ пластівця $[37,38]$. Завдяки цьому густина $j_{i R}$ струму іонів до бічного краю і густина jiL до верхівки пластівця становлять [39]:

$$
j_{i R}=f_{i R} j_{0}, \quad j_{i L}=f_{i L} j_{0},
$$

де $f_{i R}$ i $f_{i L}$ - коефріцієнти посилення потоку іонів через фрокусування відповідно до бокового та верхнього країв; $j_{0}$ - густина струму, що виділяється з плазми на підкладку, $\mathrm{A} / \mathrm{M}^{2}$.

Загальним рішенням рівняння (13) $€$ [40]:

$$
\begin{aligned}
& n_{C H x}(z)=A \cos \left[\left(\frac{j_{i R}}{e D_{C H} n_{0}} \exp \left(-\frac{e \varepsilon_{x-d i s}\left(1-\alpha_{\varepsilon}\right)}{k_{B} T_{s}}\right)\right)^{1 / 2} z\right]+ \\
& +B \sin \left[\left(\frac{j_{i R}}{e D_{C H} n_{0}} \exp \left(-\frac{e \varepsilon_{x-d i s}\left(1-\alpha_{\varepsilon}\right)}{k_{B} T_{s}}\right)\right)^{1 / 2} z\right] .
\end{aligned}
$$

Враховуючи, що густина радикалів $\mathrm{CH}_{\mathrm{x}}$ має бути $n_{\text {оснх }}$ при $z=0$, рішення рівняння (13) має вигляд

$$
n_{C H x}(z)=n_{0 C H x} \cos \left[\left(\frac{j_{i R}}{e D_{0 C H x} n_{0}} \exp \left(-\frac{e\left(\varepsilon_{x-\text { dis }}\left(1-\alpha_{\varepsilon}\right)-\varepsilon_{\alpha C H x}(E)\right)}{k_{B} T_{s}}\right)\right)^{1 / 2} z\right],
$$

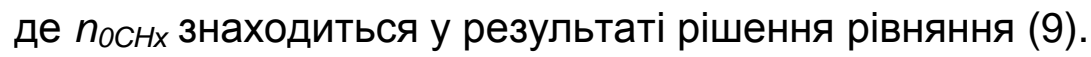

Після підстановки рівняння (12) має вигляд

$$
\begin{aligned}
& \frac{d W_{v g}(z, t)}{d t}=\frac{j_{i R}}{e} a_{0}^{3} \frac{n_{0 C H x}}{n_{0}} \exp \left(-\frac{e \varepsilon_{x-d i s}\left(1-\alpha_{\varepsilon}\right)}{k_{B} T_{s}}\right) \times \\
& \times \cos \left[\left(\frac{j_{i R}}{e D_{0 C H x} n_{0}} \exp \left(-\frac{e\left(\varepsilon_{x-\text { dis }}\left(1-\alpha_{\varepsilon}\right)-\varepsilon_{\alpha C H}(E)\right)}{k_{B} T_{s}}\right)\right)^{1 / 2} z\right]-Y \frac{j_{i R}}{e} a_{0}^{3} .
\end{aligned}
$$

Аналогічним чином визначається результуюча швидкість зростання пластівця у висоту:

$$
V_{v g-L}(z)=\frac{d L_{v g}(z, t)}{d t}=V_{v g-i o n}\left(L_{v g}\right)-V_{v g-s p u t}\left(L_{v g}\right),
$$


де доданки в правій частині рівняння являють собою іонно-стимульоване зростання і видалення матеріалу в результаті іонного бомбардування.

Після підстановки знайдено залежність швидкості зростання пластівця у висоту від часу $t$ :

$$
\begin{aligned}
& \frac{d L_{v g}(t)}{d t}=\frac{j_{i L}}{e} a_{0}^{3} \frac{n_{0 C H x}}{n_{0}} \exp \left(-\frac{e \varepsilon_{x-d i s}\left(1-\alpha_{\varepsilon}\right)}{k_{B} T_{s}}\right) \times \\
& \times \cos \left[\left(\frac{j_{i R}}{e D_{0 C H x} n_{0}} \exp \left(-\frac{e\left(\varepsilon_{x-d i s}\left(1-\alpha_{\varepsilon}\right)-\varepsilon_{\alpha C H(E)}\right)}{k_{B} T_{s}}\right)\right)^{1 / 2} L_{v g}(t)\right]-Y \frac{j_{i L}}{e} a_{0}^{3},
\end{aligned}
$$

де $j_{\text {iL }}$ - густина іонного струму, сфокусованого до верхівки пластівця; $L_{G N F O}$ початкова довжина пластівця, м.

Рішення наведеного вище рівняння можна знайти [41]:

$$
\begin{gathered}
L_{v g}(t)=\frac{2}{a} \operatorname{arctg}\left[\frac{\sqrt{D^{2}-C^{2}}}{D-C} K(t)\right], \quad\left(\frac{D}{C}\right)^{2}>1, \\
K(t)=\frac{(M(t)+1)(D-C) \operatorname{tg} \frac{a L_{0 v g}}{2}+(M(t)-1) \sqrt{D^{2}-C^{2}}}{(M(t)-1)(D-C) \operatorname{tg} \frac{a L_{0 v g}}{2}+(M(t)+1) \sqrt{D^{2}-C^{2}}}, \\
M(t)=\exp \left(\sqrt{D^{2}-C^{2}}\right),
\end{gathered}
$$

де

$$
\begin{gathered}
a=\left(\frac{j_{i R}}{e D_{0 C H x} n_{0}}\right)^{1 / 2} \exp \left(-\frac{e\left(\varepsilon_{x-d i s}\left(1-\alpha_{\varepsilon}\right)-\varepsilon_{\alpha C H x}(E)\right)}{2 k_{B} T_{s}}\right) \\
C=-Y j_{i L}\left(\frac{j_{i R}}{e^{3} D_{0 C H x} n_{0}}\right)^{1 / 2} \exp \left(-\frac{e\left(\varepsilon_{x-d i s}\left(1-\alpha_{\varepsilon}\right)-\varepsilon_{\alpha C H x}(E)\right)}{2 k_{B} T_{s}}\right), \\
D=\frac{n_{0 C H x}}{n_{0}} j_{i L}\left(\frac{j_{i R}}{e^{3} D_{0 C H x} n_{0}}\right)^{1 / 2} a_{0}^{3} \exp \left(-\frac{e \varepsilon_{x-d i s}\left(1-\alpha_{\varepsilon}\right)}{k_{B} T_{s}}\right) \times \\
\times \exp \left(-\frac{e\left(\varepsilon_{x-d i s}\left(1-\alpha_{\varepsilon}\right)-\varepsilon_{\alpha C H x}(E)\right)}{2 k_{B} T_{s}}\right)
\end{gathered}
$$

$j_{i R}$ - густина іонного струму на боковому краї; $j_{i L}$ - густина іонного струму на верхівці; $L_{G N F O}$ - початкова довжина пластівця; $D_{0 C H x}$ - коефіцієнт дифузії, що залежить від температури; $n_{0}$ - поверхнева густина атомів вуглецю (густина вузлів адсорбції); $n_{0 c H x}$ - густина радикалів $\mathrm{CH}_{\mathrm{x}}$ на поверхні підкладки $(z=0)$; $\alpha_{\varepsilon}=\varepsilon_{x i} / \varepsilon_{x-d i s}-$ відношення енергії $\varepsilon_{x i}$, отриманої радикалом $\mathrm{CH}_{\mathrm{x}}$ у результаті

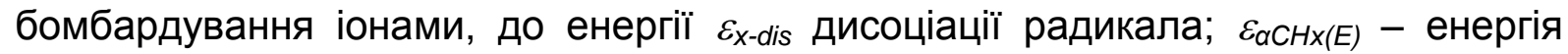
активації дифузії радикалів $\mathrm{CH}_{\mathrm{x}}$ по краю $E$; $\mathrm{a}_{0}$ - параметр кристалічної ґратки пластівця; $T_{s}$ - температура підкладки; $k_{B}$ - стала Больцмана; $e$ - заряд 
електрона; $Y$ - коефіцієнт розпилення. Випадок $(D / C)^{2}<1$ тут не розглядається, оскільки він відповідає режиму, коли розпилення поверхні $€$ домінуючим процесом.

Напівширину пластівця вертикального графену обчислюють за допомогою виразу

$$
W_{v g}(z, t)=\left(\begin{array}{l}
\frac{n_{0 C H x}}{n_{0}} \exp \left(-\frac{e \varepsilon_{x-d i s}\left(1-\alpha_{\varepsilon}\right)}{k_{B} T_{s}}\right) \times \\
\times \cos \left[\left(\frac{j_{i R}}{e D_{0 C H x} n_{0}} \exp \left(-\frac{e\left(\varepsilon_{x-d i s}\left(1-\alpha_{\varepsilon}\right)-\varepsilon_{\alpha C H}(E)\right)}{k_{B} T_{s}}\right)\right)^{1 / 2} z\right]-Y \\
\times \frac{j_{i R}}{e} a_{0}^{3} t+W_{0 v g} .
\end{array}\right.
$$

Для $z \leq L_{v g}(t)$ величина $W_{o v g} €$ напівшириною зародка графенового пластівця на початку стадії вертикального зростання, м.

Відповідно до виразу (22) максимальна висота пластівця обмежена, і межа для $t \rightarrow \infty$ визначається виразом

$$
L_{v g}(\infty)=\frac{2}{a} \operatorname{arctg} \sqrt{\frac{D+C}{D-C}} .
$$

Слід підкреслити, що різні мікроскопічні параметри залежать від параметрів оброблення: густина $n_{C H 4}$ адсорбованих молекул $\mathrm{CH}_{4}$ i

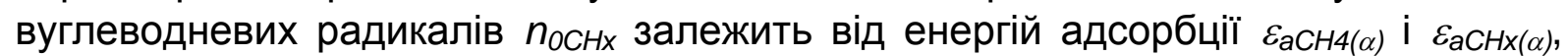
парціального тиску газу $P_{C H 4}$, температури підкладки $T_{s}$, середньої густини струму іонів јо до підкладки. У свою чергу, енергії адсорбції залежать від енергії іонів (отже, від електричного потенціалу підкладки $U_{s}$ ) через залежність від поверхневого стану (згідно з припущеннями, енергії збільшуватимуться зі збільшенням хаосу у кристалічній ґратці поверхні). Взагалі, залежність (22) передбачає режим насичення, яке пов'язане 3 процесом дисоціації $\mathrm{CH}_{\mathrm{x}}$ на бічному краї пластівця. На процес дисоціації сильно впливає іонний струм, причому більш високі струми пов'язані з вищими швидкостями дисоціації. Насичення значною мірою залежить від енергій адсорбції газів та енергії активації дифузії. Різниця між значеннями параметрів пояснюється різницею в кількості дефектів, що утворюються на краю графенового пластівця при бомбардуванні іонами - чим менше енергія іона, тим менше густина дефектів і менше енергія активації дифузії.

\section{2. Результати розрахунку}

Велика кількість параметрів, які використовуються в моделі і не піддаються вимірюванню, передбачає деяку довільність при виборі значень параметрів. Тому було застосовано наступну процедуру, яка відповідала чисельним результатам експериментам. Перш за все, енергії адсорбції $\varepsilon_{a H 2(\alpha)}$ та $\varepsilon_{a}{ }_{44}(\alpha)$ визначали з умови підтримки густини молекул на поверхні підкладки при підвищених температурах (близько $1000^{\circ} \mathrm{C}$ ). Розрахунки показують, що зростання нанопластівців можливе, коли поверхневі густини водню та метану приблизно дорівнюють $10^{-4} n_{0}$ та $10^{-2} n_{0}$ при температурі близько $1000{ }^{\circ} \mathrm{C}$; відповідні енергії $\varepsilon_{a H 2(\alpha)}=1.5$ еВ та $\varepsilon_{a C H 4(\alpha)}=2.8$ eВ. Значення енергії адсорбції 
для метану значно перевищує значення, розраховане за теорією функціоналу густини (DFT) для адсорбції на ідеальному графені $(0,45 \mathrm{eB})$, але порівнюється з енергією адсорбції на графені, легованому фосфором (2,13 еВ), і становить величину, яка набагато менше енергії адсорбції на графені, легованому алюмінієм (3,28 еВ) [42]. Енергія адсорбції водню на графені, отримана дослідженнями DFT та Монте-Карло, становить близько 0,1 еВ [43], що також набагато менше, ніж зазначена вище енергія.

Наступним кроком при дослідженні зв'язку між енергією та густиною струму іонів у розробленій моделі було визначено енергію активації дифузії $\varepsilon_{a H}(\alpha)$ атомів водню. При цьому початкове значення густини іонного струму відповідає густині плазми, яка $€$ характерною для застосованого джерела плазми [44,45]. Якщо чисельні результати не відповідають експерименту, енергія $\varepsilon_{a H}$ збільшується, і в тому випадку, коли збільшення до значення 1,9 еВ не дає збігу, в моделі збільшується густина іонного струму. Це зумовлено тим фактом, що для атомарного водню енергії зв'язку лежать у діапазоні 0,47...1,9 еВ (більшість результатів відповідає діапазону 0,6..0,85 еВ) [46]. Збільшення енергії активації дифузії атома водню також пояснюється ефектом бомбардування іонами, тоді як збільшення густини іонного струму змушує зробити висновок про потік іонів, що фокусується на гострих краях графенового пластівця. Більше того, коли всі зазначені вище підходи не дозволяють отримати чисельні результати близькими до експерименту (наприклад, щоб пояснити співвідношення довжини пластівця до його напівширини), розглядається можливість перерозподілу густини іонного струму вздовж бічного та верхнього країв графенового пластівця.

Енергії дисоціації $\varepsilon_{d H 2}$ та $\varepsilon_{d c H 4}$ досить високі $(4,52 \mathrm{eB}$ та 4,95 еВ відповідно) [47, 48], тому термічна дисоціація не впливає на процес генерації атомів водню та вуглеводневих радикалів на поверхні для розглянутого діапазону температур за відсутності каталізатора. Слід підкреслити, що наявність каталізатора зменшує енергію дисоціації та значно сприяє кінетиці процесу, і цей факт відображений у запропонованій моделі.

Згідно 3 розрахунками, початкова прямокутна форма зародка вертикального графену може зберігатися протягом досить тривалого періоду росту (до двох годин, як показано на рис. 2,3). Потім форма поступово змінюється - чим ближче довжина пластівця до максимального значення, описаного режимом насичення, тим більше фрорма пластівця наближається до косинусоїдального розподілу. Хоча в точці насичення вертикальний ріст припиняється, пластівець продовжує зростати в ширину. Насправді характер зростання пластівця може різко змінитися на певній стадії внаслідок, наприклад, зростання вуглецевих нанотрубок на краях пелюстки [49]. Однак ці зміни не враховують у запропонованій моделі.

В експерименті Занга [50] продемонстровано нелінійне зростання пластівця у часі: він зростає до висоти лише 1,2 мкм за час зростання 5 хв., потім зростає до висоти 4,7 мкм, коли час зростання подовжується до 20 хв., а за час зростання 60 хв. висота збільшується до 38 мкм. Ця досить несподівана

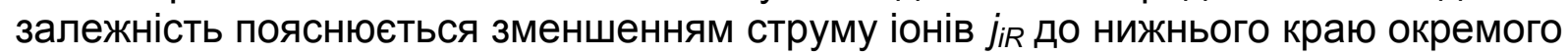
пластівця внаслідок росту всього масиву пластівців вертикального графену, коли процес розщеплення радикалів $\mathrm{CH}_{\mathrm{x}}$ на бічній кромці пластівців стає менш ефективним. Одночасне зменшення втрат радикалів $\mathrm{CHx}$ на бічній кромці 
призводить до збільшення потоку радикалів до вершини пластівця. Для нелінійної залежності можна записати відповідні густини струму іонів у вигляді

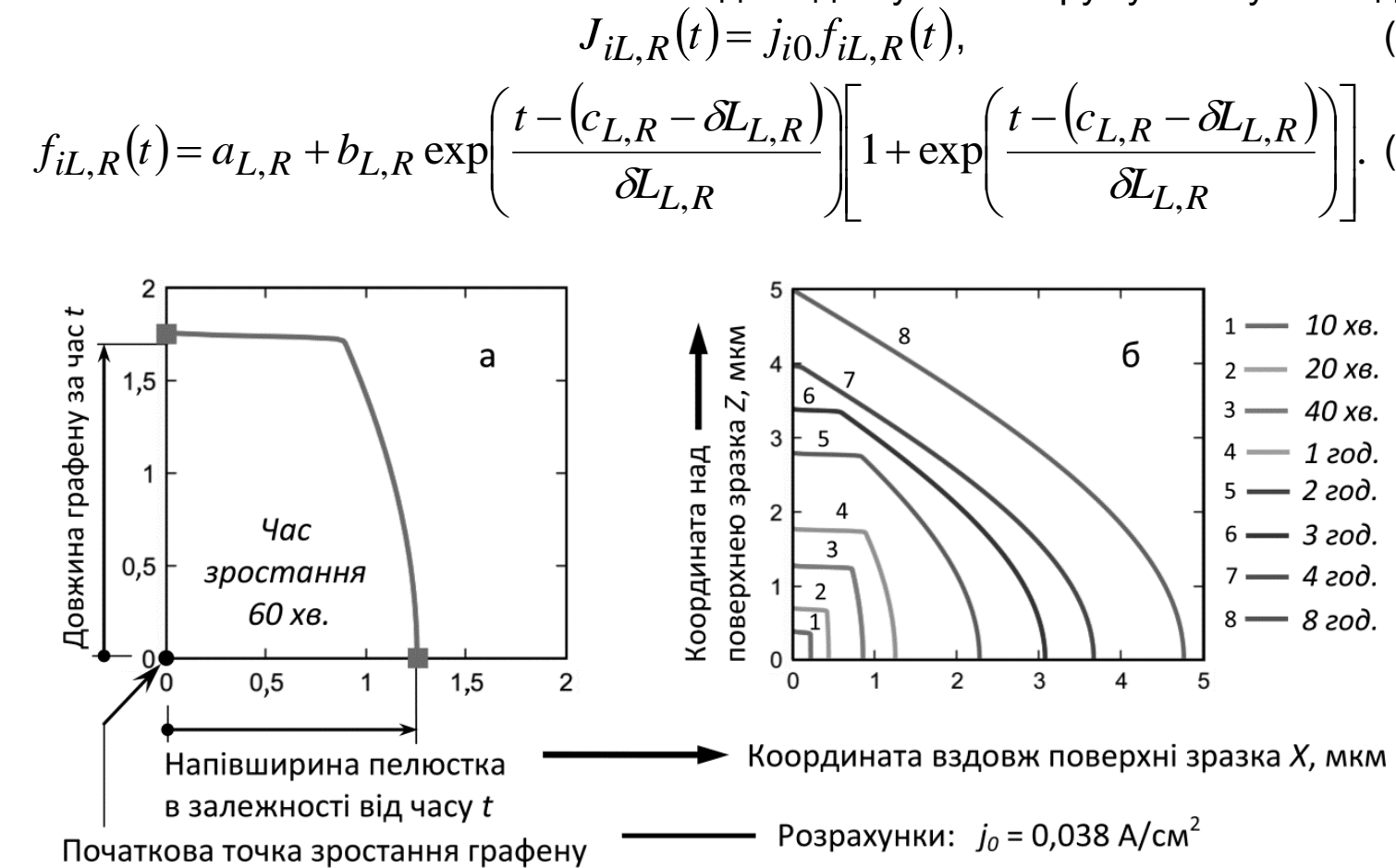

Початкова точка зростання графену

- Експеримент (Kurita): $P_{C H \mathrm{x}}=0,18$ Па; $T_{s}=550^{\circ} \mathrm{C}$

Рис. 2. Розвиток форми графенового пластівця з часом: $j_{0}=0,038 \mathrm{~A} / \mathrm{cm}^{2}$, $P_{C H 4}=0,18 \Pi a, T_{s}=550{ }^{\circ} \mathrm{C}:$ a - розрахунок з експериментом; б - розрахунок

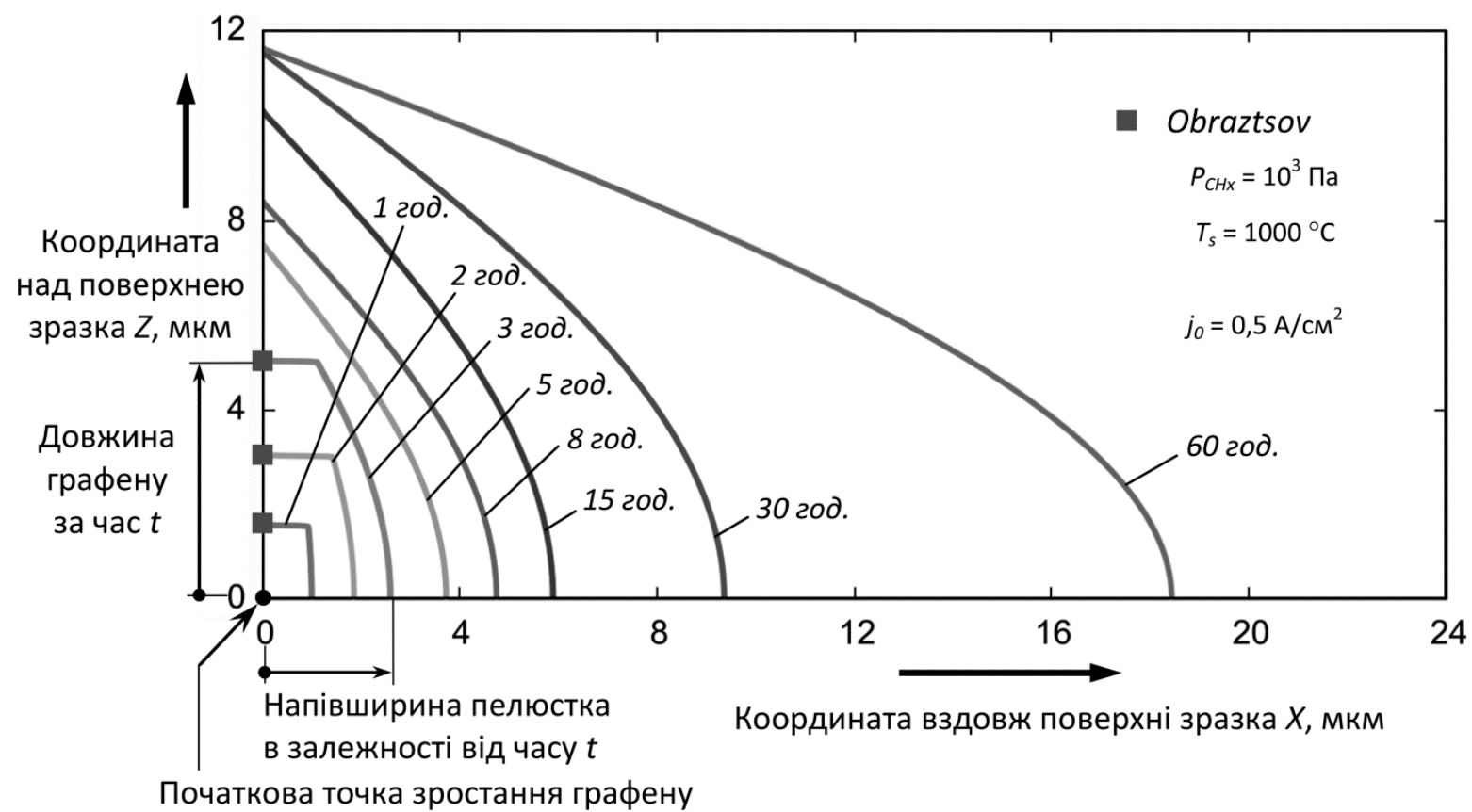

Рис. 3. Розвиток форми графенового пластівця з часом: $j_{0}=0,5 \mathrm{~A} / \mathrm{cm}^{2}$, $P_{C H 4}=10^{3} \mathrm{~Pa}, T_{s}=1000^{\circ} \mathrm{C}$ 
Останній вираз має фрорму розподілу Фермі-Дірака [33] і дозволяє описати поступове змінення певної величини між завданими постійними рівнями.

Згідно з розрахунками, густина іонного струму $j_{i L}$ до вершини пластівця майже в шість разів збільшується порівняно з початковим значенням, тоді як густина струму на боковому краї пелюстки демонструє лише трикратне зменшення; таке ж збільшення обчислюється для експериментів Куріти. Крім того, порівняння з експериментальними даними [26] показує різницю в енергії $\varepsilon_{x i}$, отриманій радикалом $\mathrm{CHx}$ як наслідок бомбардування іонами, та енергії $\varepsilon_{x-d i s}$ дисоціації радикала, що описується співвідношенням $\alpha_{\varepsilon}=\varepsilon_{x} / \varepsilon_{x}$-dis. Відповідність експериментальним даним забезпечується при значеннях $\alpha_{\varepsilon}=0.99$, отже, бомбардування іонами призводить до зміни іонно-стимульованої дифузії на режим іонного змішування.

Запропонована модель була використана для розрахунку процесів зростання графенових пластівців у різних умовах. На рис. 4 показані дані експериментів Ванга [51], які були використані в моделі разом із описаною вище залежністю довжини пластівця від часу для визначення енергій адсорбції та енергії активації дифузії, наведених у таблиці 1 [26].

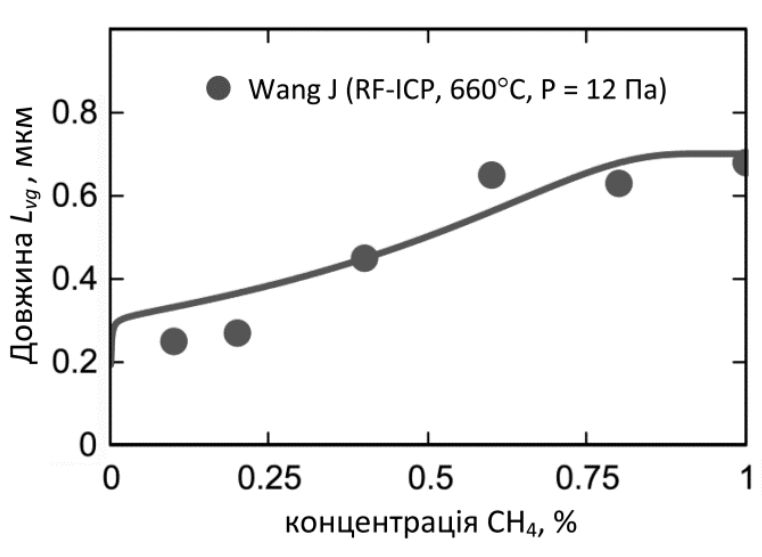

a

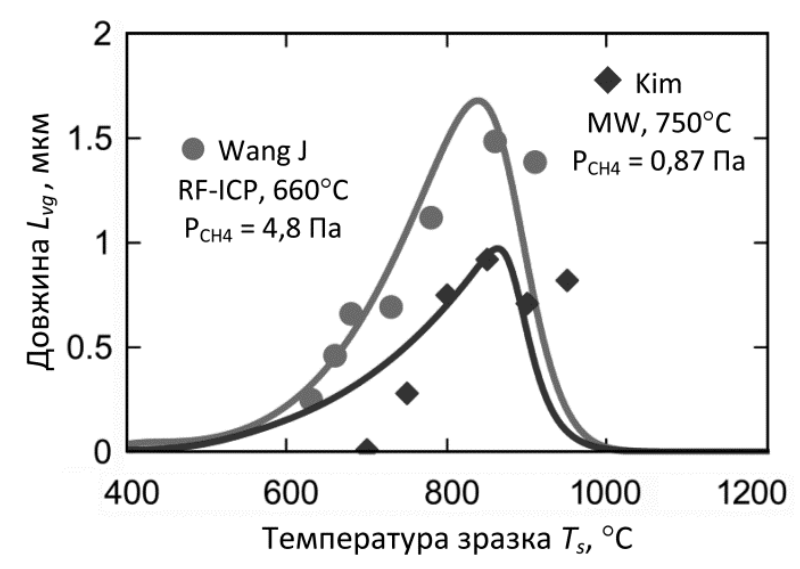

6

Рис. 4. Залежність довжини пластівця від часу при різних умовах зростання: а -довжина пластівця залежно від концентрації газу-попередника (вуглеводню), $P_{C H x}=4.8 П a, T_{s}=660^{\circ} \mathrm{C}, j_{i}=70 \mathrm{~A} / \mathrm{m}^{2}$ (Ванг [51]); б - довжина пластівця залежно від температурі зразка (Кім [52]). Густина струму іонів і температура підкладки впливають як на максимальну довжину, так і на швидкість росту пластівця, тоді як тиск газу контролює лише швидкість зростання (б). Густина іонного струму є більш універсальним інструментом для змінення морфології пластівця порівняно з температурою, оскільки дозволяє досягти заданого значення довжини пластівця за набагато коротший проміжок часу, при цьому більші струми відповідають коротшому часу до насичення та нижчим максимальним довжинам пластівця

Як видно, десятикратне збільшення концентрації вуглецевомісткого газу при постійному загальному тиску в реакторі приводить до трикратного збільшення довжини графенового пластівця. Згідно 3 розрахунками експериментальні точки знаходяться близько до тієї частини розрахункової кривої, що описує режим насичення при встановлених енергіях, і це насичення 
відбувається приблизно при 80\%-ній концентрації $\mathrm{CH}_{4}$ (рис. 1, а). Встановлено, що причиною насичення $є$ бомбардування іонами, оскільки воно визначає значне збільшення енергії адсорбції та відповідний зсув відносної густини метану, адсорбованого на поверхні, до режиму насичення (тобто $n_{C H 4} / n_{0} \approx 1$ ). Однак для режимів адсорбції, далеких від режиму насичення метаном, збільшення довжини пластівця при залежності від тиску метану може бути набагато вищим.

На рис. 4, б показані експериментальні дані, отримані Вангом [51] та Кімом [52], а також розрахункові криві. Можна оцінити причини існування верхньої та нижньої меж температури для зростання наноструктури. При низьких температурах $\sim 550^{\circ} \mathrm{C}$ дифузія радикалів вздовж поверхні $€$ занадто низькою для створення наноструктури, тоді як висока температура $\sim 1000{ }^{\circ} \mathrm{C}$ сильно обмежує поверхневу заселеність «будівельними блоками» (тобто радикалів $\mathrm{CH}_{\mathrm{x}}$ ) для розглянутого діапазону тиску газу-попередника ( 1..10 Па). Отже, чим вищий тиск газу-попередника, тим кращі умови для фоормування наноструктури. Чим нижче тиск, тим вужчим $€$ діапазон температур для росту наноструктур. Рис. 5 дає пояснення існування оптимального діапазону температур для зростання наноструктури. Збільшення температури підкладки призводить до зменшення відносної заселеності адсорбційних вузлів, тобто щільність адсорбованих на поверхні графену радикалів $\mathrm{CH}_{\mathrm{x}}$ зменшується відповідно до ізотерми Ленгмюра (рис. 5, а). У той же час дифузія радикалів уздовж поверхні підкладки значно посилюється в міру підвищення температури. Імовірність адсорбції радикалів та активації дифузії, яка $\epsilon$ добутком $\frac{P_{C H x}}{P_{0 C H x}+P_{C H x}} \exp \left(-\frac{e \varepsilon_{a C H x}(E)}{k_{B} T_{s}}\right)$, може служити узагальненим критерієм для досягнення оптимального зростання наноструктур в умовах різної температури оброблення та тиску газу (рис. 5, б). Згідно з розрахунками, тиск газу дозволяє розширити діапазон, у межах якого може бути досягнуто ефективне зростання, проте слід враховувати вплив тиску на режими плазмового розряду.

Для аналізу впливу різних параметрів модель була використана для розрахунку довжини пластівця вертикального графену за різних умов зростання. При цьому процес зростання розглядався окремо від утворення пластівців на поверхні зразку для густин радикалів $\mathrm{CH}_{\mathrm{x}}$ та атомів водню приблизно $10^{-2}$ та $10^{-5}$ відповідно, що є типовими значеннями для зростання, відповідно до числових результатів. Як параметри розглядалися густини іонного струму $j_{i L}, j_{i R}$ (у розрахунках було зроблено припущення, що $\left.j_{i R}=0.5 j_{i L}\right)$, тиск газу-попередника (вуглеводню) $P_{C H x}$ та температура підкладки $T_{s}$. Лінія $j_{i L}=0.5 \mathrm{~A} / \mathrm{cm}^{2}$ на рис. 6 , a, лінія $P_{C H x}=10^{3}$ Па на рис. 6 , б, та лінія $T_{s}=1000^{\circ} \mathrm{C}$ на рис. 6 , в відповідають умовам зростання нанопластівців в експерименті, проведеному А. Образцовим та його колегами [53]. Інші криві отримують шляхом змінення останніх трьох параметрів. Розглядаючи розраховану залежність $L_{v g}(t)$ від густини струму іонів $j_{i}$, слід зробити висновок, що загалом ця залежність має режим насичення. На практиці час зростання графену коротше часу для досягнення насичення, i зазвичай спостерігається лінійна залежність.

Таким чином, незважаючи на те, що чисельні експерименти свідчать про можливість прямого осадження радикалів $\mathrm{CH}_{\mathrm{x}}$ із плазми на краю вертикального графену, запропонована модель зростання базується на припущенні про визначальну роль поверхневої дифузії радикалів $\mathrm{CH}_{\mathrm{x}}$ вздовж поверхні зразка і 
знизу доверху пластівця вертикального графену. Показано, що такий підхід також може описати це квазілінійне зростання (рис. 6, а).

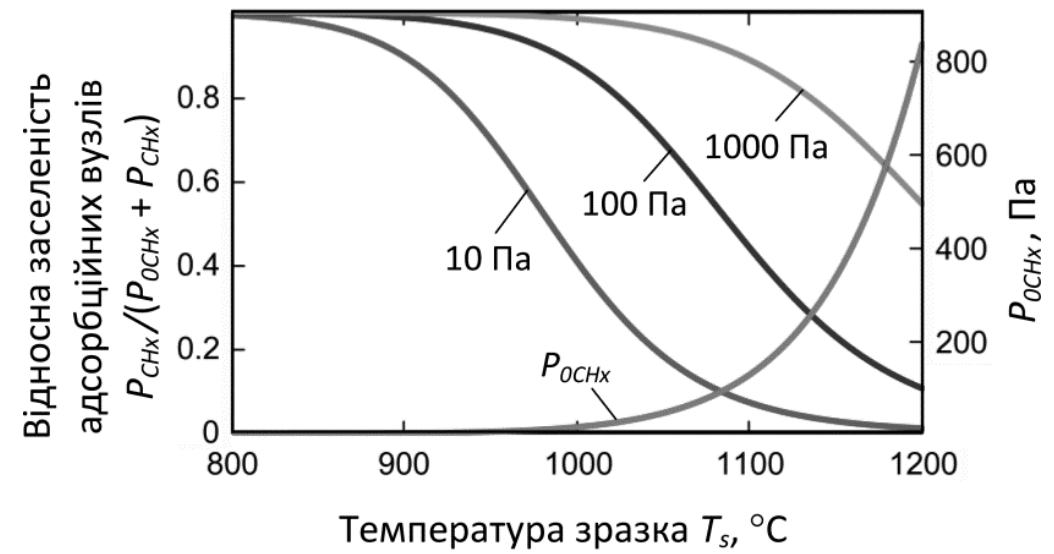

a

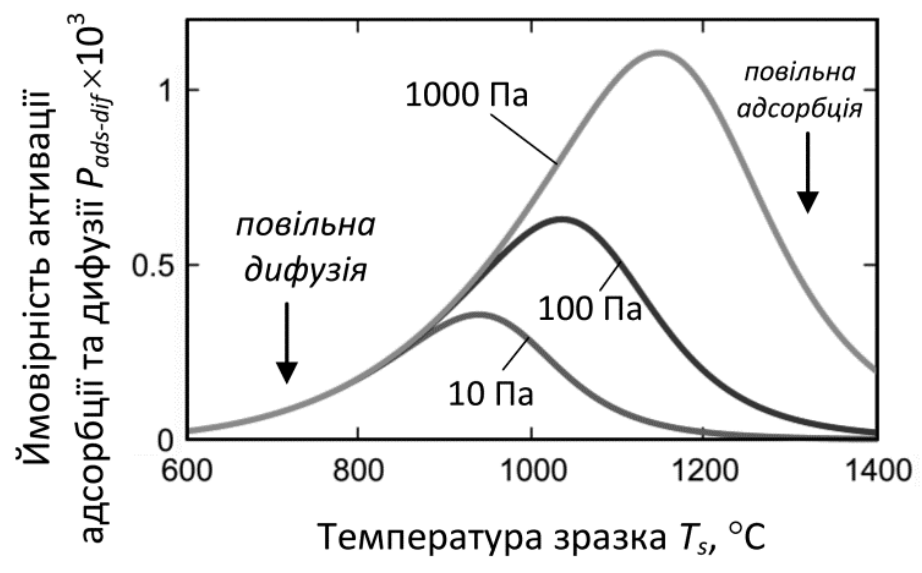

6

Рис. 5. Результати розрахунку залежно від температури зразка: a - відносна сукупність адсорбційних вузлів $P_{C H x} /\left(P_{O C H x}+P_{C H x}\right)$ та значення

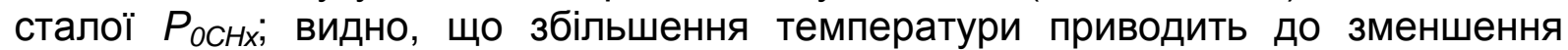
відносної заселеності адсорбційних вузлів; б - ймовірність адсорбції радикалів та активації дифузії описує діапазон оптимальних умов для зростання графенового пластівця, тобто температуру зразка та тиск вуглеводневого газу

Густина іонного струму і температура підкладки (зразка) впливають як на максимальну довжину, так і на швидкість зростання вертикального графену (рис. 6, г, е), тоді як тиск газу контролює лише швидкість зростання (рис. 6, д). Густина іонного струму $є$ більш універсальним інструментом для змінення морфології графену порівняно з температурою, оскільки дозволяє досягти заданого значення довжини пластівця за набагато коротший проміжок часу, при цьому більші струми відповідають коротшому часу до насичення та нижчим максимальним довжинам пелюстки. Залежності максимальної довжини графенової пелюстки $L_{\max }$, швидкості зростання $V_{\max }$ та часу зростання $t_{\max }\left(L_{\max }\right)$ від умов зростання: (рис. 6, г) $P_{C H x}=10^{3} \Pi \mathrm{la}, T_{s}=1000^{\circ} \mathrm{C}$; (рис. 6, д) $j_{i L}=0.5 \mathrm{~A} / \mathrm{cm}^{2}, \quad T_{s}=1000^{\circ} \mathrm{C} ; \quad$ (рис. 6, e) $j_{i L}=0.5 \mathrm{~A} / \mathrm{cm}^{2}, \quad P_{C H x}=10^{3} \Pi$ a. Розрахунки, проведені за допомогою виразу (29) $3 \beta=0,9$, підтверджують 
ефрективність іонного струму як основного параметра для контролю тривалості та часу зростання графену, оскільки збільшення густини струму на три порядки (що можна впровадити у сучасних плазмових реакторах) призводить до збільшення швидкості зростання на три порядки при супутньому зменшенні максимальної довжини в чотири рази (рис. 6, г).

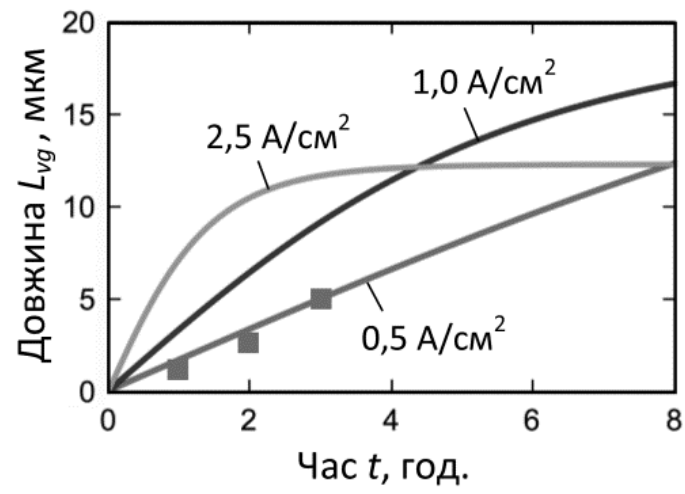

a

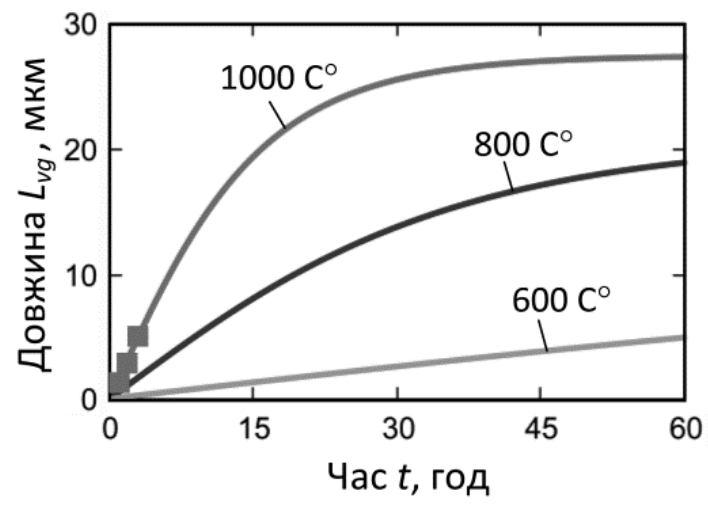

B

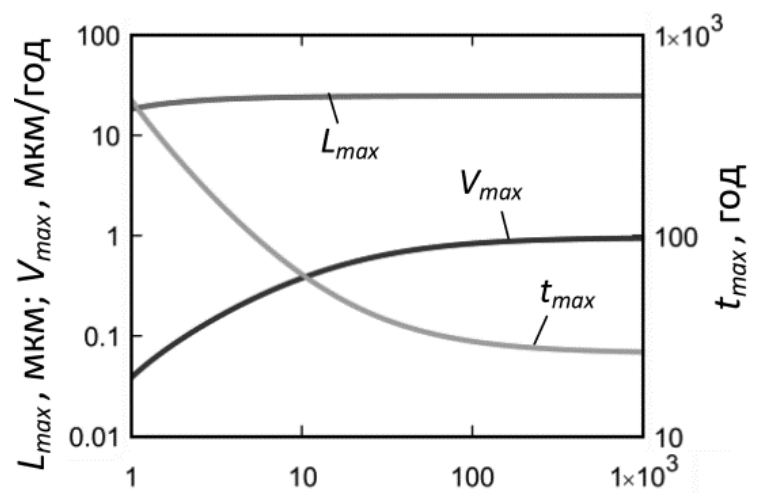

Тиск вуглецевомісткого газу $P$, Па

д

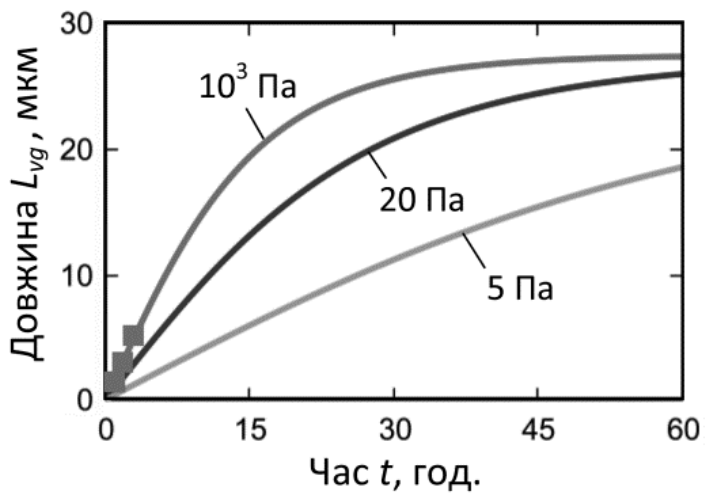

6

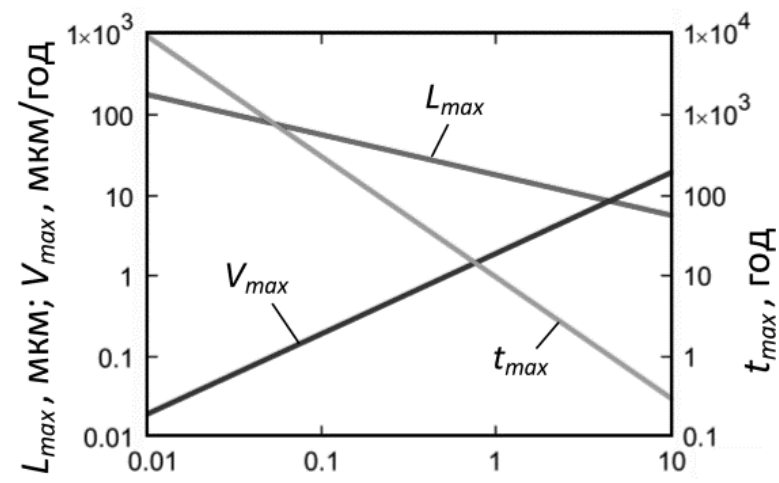

Густина іонного струму $j_{0}, \mathrm{~A} / \mathrm{M}^{2}$

$\Gamma$

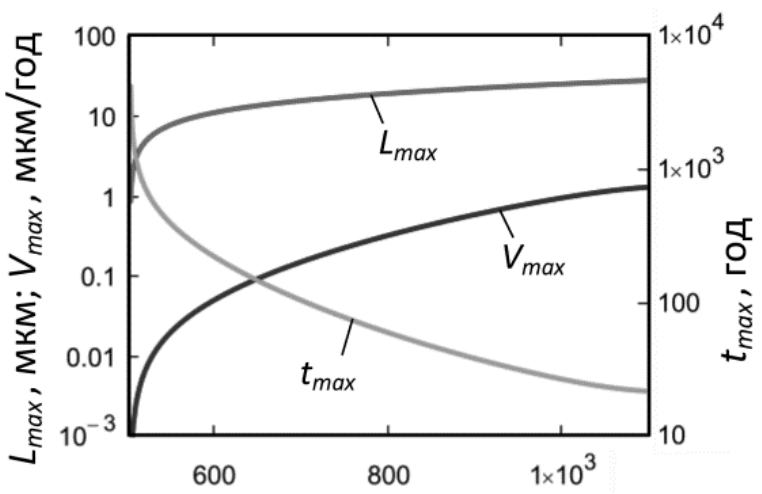

Температура зразка $T_{s},{ }^{\circ} \mathrm{C}$

e

Рис. 6. Залежність довжини графенового пластівця від часу для різних умов зростання: a $-P_{C H x}=10^{3} \Pi a, T_{s}=1000{ }^{\circ} \mathrm{C}$, jiL - параметр; $\sigma-j_{i L}=0.5 \mathrm{~A} / \mathrm{cm}^{2}$, $T_{s}=1000^{\circ} \mathrm{C}$, тиск газу попередника (вуглеводню) $€$ параметром; в - jiL $=0.5 \mathrm{~A} / \mathrm{cm}^{2}, P_{C H x}=10^{3}$ Па, параметром $€$ температура зразка; залежність максимальної довжини пластівця, максимальної швидкості та часу зростання 
від: г - густини іонного струму; д - тиску вуглецевомісткого газу; е температури зразка

Навпаки, при підвищенні температури з $500{ }^{\circ} \mathrm{C}$ до $600{ }^{\circ} \mathrm{C}$ також збільшуються $L_{\max }$ і $V_{\max }$ - на порядок і на три порядки, відповідно; більша частина збільшення відповідає діапазону температур від $500{ }^{\circ} \mathrm{C}$ до $600{ }^{\circ} \mathrm{C}$, а $L_{\text {max }}$ залишається майже постійним при температурах, більших $600{ }^{\circ} \mathrm{C}$ (рис. $6, \mathrm{e}$ ). Тиск газу (рис. 6, д) забезпечує найбільш ефективний контроль швидкості зростання графенових пластівців.

Однак, якщо швидкість зростання визначається як відношення довжини пластівця графену до часу зростання, то швидкість зростання збільшується із підвищенням температури, а потім падає, що добре узгоджується 3 експериментальними даними [51]. У сукупності змінення тиску і температури можна використовувати для ефрективного контролю густини іонного струму, тим самим контролюючи динаміку зростання.

\section{Висновки}

Отже, стимульована іонами дисоціація молекул вуглеводнів, адсорбованих підкладкою, є основним джерелом вуглеводневих радикалів, які $\epsilon$ будівельними блоками для зростання вертикального графену. На дисоціацію сильно впливає не тільки інтенсивність струму іонів, але й енергія іонів, оскільки в умовах іонного бомбардування утворюється велика кількість поверхневих дефектів. Цей процес змінює адсорбцію з фрізичної на хімічну; чим більше енергія іонів, тим більше енергія адсорбції і тим більше густина адсорбованих атомів і молекул на поверхні зразка. Таким чином, потік іонів забезпечує значне покриття підкладки вуглеводневими радикалами ( 1\%) при підвищених температурах $\left(\sim 1000^{\circ} \mathrm{C}\right)$.

Бомбардування іонами є причиною процесу зростання на бічних і верхніх краях графенового пластівця; вуглеводневі радикали дифундують від підкладки до вершини пластівця і беруть участь у реакції на його краях, причому швидкість реакції пропорційна потоку іонів із плазми. Енергія іонів також впливає на дифузію радикалів: чим менше енергія іона, тим менше енергія активації дифузії вздовж менш дефектної поверхні.

Температура зразка $є$ іншим важливим параметром, який суперечливо впливає на процес росту: при низькій температурі адсорбція з газової фрази $є$ більш інтенсивною, проте процеси дифузії сповільнюються; підвищені температури діють протилежно. Температуру можна регулювати, змінюючи потужність розряду і охолоджуючи підкладку.

Поверхнева густина графенових пластівців, яку можна контролювати на стадії зародження, сильно впливає на висоту пластівців через перерозподіл потоків іонів під час зростання: у міру зростання пластівців густина струму іонів до бічного краю пластівця зменшується, а на верхній край збільшується. Причиною такого перерозподілу $\epsilon$ екранування, спричинене сусідніми пластівцями. При щільних масивах графену втрати радикалів на боці пластівців сильно зменшуються через низьку густину іонного струму, і майже весь потік радикалів доставляється з поверхні зразка на верх пластівця для участі в процесі зростання у довжину. Внаслідок цього змінення від зростання в умовах бомбардування іонами бічного краю пластівця 3 відповідною втратою вуглецевих радикалів до доставки радикалів без втрат на верх пластівця 
приводить до змінення залежності довжини пластівця графену у часі: від кривої із насиченням або квазілінійною залежністю від часу - до параболічної залежності. Припущення про поверхневу дифузію вуглеводневих радикалів як про домінуючий механізм зростання узгоджується 3 існуючими експериментальними даними; наведені результати підтверджують теоретичну модель, а також привносять більш глибоке розуміння фрізики фрормування вертикального графену.

\section{Подяки}

Автор висловлює подяку Національному фонду досліджень України за підтримку (конкурс «Підтримка досліджень провідних та молодих учених», номер проєкту 2020.02/0119).

\section{Список літератури}

1. Nanoscale Memory Devices / A. Chung, J. Deen, J. S. Lee, M. Meyyappan // Nanotechnology. - 2010. - №21. - P. 412001.

2. Ostrikov, K. Plasma nanoscience: setting directions, tackling grand challenges / K. Ostrikov, U. Cvelbar, A. B. Murphy // Journal of Physics D: Applied Physics. - 2011. - No. 44. - P. 174001.

3. Hierarchical multicomponent inorganic metamaterials: intrinsically driven self-assembly at the nanoscale / I. Levchenko, K. Bazaka, M. Keidar, S. Xu, J. Fang // Advanced Materials. - 2018. - No. 30. - P. 1702226.

4. Structural stability, magneto-electronics and spin transport properties of triangular graphene nanoflake chains with edge oxidation / R. Hu, Z. Q .Fan, C. H. Fu, L. Y. Nie, W. R. Huang, Z. H. Zhang // Carbon. - 2018. - No. 126. - P. 93-104.

5. Scalable graphene production: perspectives and challenges of plasma applications / I. Levchenko, K. Ostrikov, J. Zheng, X. Li, M. Keidar, K. B. K. Teo // Nanoscale. - 2016. - No. 8. - P. 10511.

6. Wohner, N. Energetic stability of graphene nanoflakes and nanocones / N. Wohner, P. Lam, K. Sattler // Carbon. - 2014. - No. 67. - P. 721-735.

7. Plasma under control: Advanced solutions and perspectives for plasma flux management in material treatment and nanosynthesis / O. Baranov, K. Bazaka, H. Kersten, M. Keidar, U. Cvelbar, S. Xu, I. Levchenko // Applied Physics Reviews. 2017. - No. 4. - P. 041302.

8. Plasma-assisted self-organized growth of uniform carbon nanocone arrays / Z. L. Tsakadze, I. Levchenko, K. Ostrikov, S. Xu // Carbon. - 2007. - No. 45. P. 2022-2030.

9. Synthesis and in-situ oxygen functionalization of deposited graphene nanoflakes for nanofluid generation / U. Legrand, N.-Y. Mendoza Gonzalez, P. Pascone,

J.-L. Meunier, D. Berk // Carbon. - 2016. - No. 102. - P. 216-223.

10. Vovusha, $H$. Adsorption of Nucleobases on 2D Transition-Metal Dichalcogenides and Graphene Sheet: A First Principles Density Functional Theory Study / H. Vovusha, S. Sanyal, B. Sanyal // Journal of Physical Chemistry Letters. 2013. - No. 4. - P. 3710-3718.

11. Review of Electrochemical Capacitors Based on Carbon Nanotubes and Graphene / J. Li, X. Cheng, A. Shashurin, M. Keidar // Graphene. - 2012. - No. 1. P. 1-13. 
12. Chen, J. Graphene Materials for Electrochemical Capacitors / J. Chen, C. Li, G. Shi // Journal of Physical Chemistry Letters. - 2013. - No. 4. - P. 1244-1253.

13. Plasma meets metamatertials: Three ways to advance space micropropulsion systems / I. Levchenko, S. Xu, O. Cherkun, O. Baranov, K. Bazaka // Advances in Physics X. - 2020. -V. 6, No. 1. - P. 1834452.

14. Laminated Magnetic Graphene with Enhanced Electromagnetic Wave Absorption Properties / X. Sun, J. He, G. Li, J. Tang, T. Wang, Y. Guo, H. Xue // Journal of Materials Chemistry C. - 2013. - No. 1. - P. 765-777.

15. Carbon Nanotube with Chemically Bonded Graphene Leaves for Electronic and Optoelectronic Applications / K. Yu, G. Lu, Z. Bo, S. Mao, J. Chen // Journal of Physical Chemistry Letters. - 2011. - No. 2. - P. 1556-1562.

16. Enhanced Field Emission of Vertically Oriented Carbon Nanosheets Synthesized by $\mathrm{C}_{2} \mathrm{H}_{2} / \mathrm{H}_{2}$ Plasma Enhanced CVD / M. Y. Zhu, R. A. Outlaw, M. Bagge-Hansen, H. J. Chen; D. M. Manos // Carbon. - 2011. - No. 49. - P. 25262531.

17. Low-Temperature Graphene Synthesis Using Microwave Plasma CVD / T. Yamada, J. Kim, M. Ishihara, M. Hasegawa // Journal of Physics D: Applied Physics. - 2013. - No. 46. - P. 063001.

18. Hierarchical vertical graphene nanotube arrays via universal carbon plasma processing strategy: A platform for high-rate performance battery electrodes / B. Ouyang, D. Chao, G. Jia, Z. Zhang, H. J. Fan, R. S. Rawat // Energy Storage Materials. - 2019. - No. 18. - P. 462-469.

19. Vertically-oriented graphene nanowalls: Growth and application in Li-ion batteries / Q. Yang, J. Wu, S. Li, L. Zhang, J. Fu, F. Huang, Q. Cheng // Diamond and Related Materials. - 2019. - No. 91. - P. 54-63

20. Oriented Carbon Nanostructures by Plasma Processing: Recent Advances and Future Challenges / N. M. Santhosh, G. Filipič, E. Tatarova, O. Baranov, H. Kondo, M. Sekine, M. Hori, K. Ostrikov, U. Cvelbar // Micromachines. - 2018. V. 9, No. 11. - P. 565.

21. Multi-Pin DC Glow Discharge PECVD for Uniform Growth of Vertically Oriented Graphene at Atmospheric Pressure / Z. Bo, W. Ma, P. Wang, E. Wu, W. Yang, K. Yu, X. Zhang, J. Yan, K. Cen // Physica Status Solidi B. - 2014. - No. 251. - P. 155-161.

22. Fast Response, Vertically Oriented Graphene Nanosheet Electric Double Layer Capacitors Synthesized from $\mathrm{C}_{2} \mathrm{H}_{2}$ / M. Cai, R. A. Outlaw, R. A. Quinlan, D. Premathilake, S. M. Butler, J. R. Miller // ACS Nano. - 2014. - No. 8. - P. 58735882.

23. Xie, L. Selective Etching of Graphene Edges by Hydrogen Plasma / L. Xie, L. Jiao, H. Dai // Journal of the American Chemical Society. - 2010. - No. 132. P. 14751-14753.

24. Growth of Graphene on $\mathrm{Cu}$ by Plasma Enhanced Chemical Vapor Deposition / T. Terasawa, K. Saiki // Carbon. - 2012. - No. 64. - P. 869-874.

25. Towards a General Growth Model for Graphene CVD on Transition Metal Catalysts / A. Cabrero-Vilatela, R. S. Weatherup, P. Braeuninger-Weimer, S. Caneva, S. Hofmann // Nanoscale. - 2016. - No. 8. - P. 2149-2158.

26. Formation of vertically oriented graphenes: what are the key drivers of growth? / O. Baranov, I. Levchenko, S. Xu, J. W. M. Lim, U. Cvelbar and K. Bazaka // 2D Materials. - 2018. - No. 5. - P. 044002. 
27. Tuning and fine morphology control of natural resource-derived vertical graphene / S. Alancherry, M.V. Jacob, K. Prasad, J. Joseph, O. Bazaka, R. Neupane, O. K. Varghese, O. Baranov, S. Xu, I. Levchenko, K. Bazaka // Carbon. 2020. - No. 159. - P. 668-685.

28. Vertical Growth of Carbon Nanowalls Using RF Plasma-Enhanced Chemical Vapor Deposition / K. Shiji, M. Hiramatsu, A. Enomoto, M. Nakamura, H. Amano, M. Hori // Diamond and Related Materials. - 2005. - No. 14. - P. 831834.

29. A Growth Mechanism for Free-Standing Vertical Graphene / J. Zhao, M. Shaygan, J. Eckert, M. Meyyappan, M. H. Rummeli // Nano Letters. - 2014. No. 14. - P. 3064-3071.

30. Mehdipour, H. Kinetics of Low-Pressure, Low-Temperature Graphene Growth: Toward Single-Layer, Single-Crystalline Structure / H. Mehdipour, K. Ostrikov // ASC Nano. - 2012. - V. 6, No. 11. - P. 10276-10286.

31. Zhang, Z. Vertically Aligned Graphene Nanosheet Arrays: Synthesis, Properties and Applications in Electrochemical Energy Conversion and Storage / Z. Zhang, C.-S. Lee, W. Zhang // Advanced Energy Materials. - 2017. - No. 7. P. 1700678.

32. Initial growth process of carbon nanowalls synthesized by radical injection plasmaenhanced chemical vapor deposition / S. Kondo, S. Kawai, W. Takeuchi, K. Yamakawa, S. Den, H. Kano, M. Hiramatsu, M. Hori // Journal of Applied Physics. 2009. - No. 106. - P. 094302.

33. Kittel, C. Thermal physics / C. Kittel, H. Kroemer. - New York: W. H. Freeman and Co. -1980 . -475 p.

34. Graphene flakes in arc plasma: conditions for the fast single-layer growth / I. Levchenko, U. Cvelbar, M. Keidar // Graphene. - 2016. - No. 5. - P. 81-89.

35. A Mechanism for Carbon Nanosheet Formation / M. Zhu, J. Wang, B. C. Holloway, R. A. Outlaw, X. Zhao, K. Hou, V. Shutthanandan; D. M. Manos // Carbon. - 2007. - No. 45. - P. 2229-2234.

36. Growth dynamics of copper oxide nanowires in plasma at low pressures / G. Filipič, O. Baranov, M. Mozetič, U. Cvelbar // Journal of Applied Physics. - 2015. No. 117. - P. 043304.

37. Plasma-enhanced chemical vapor deposition synthesis of vertically oriented graphene nanosheets / Z. Bo, Y. Yang, J. Chen, K. Yu, J. Yan, K. Cen // Nanoscale. - 2013. - No. 5. - P. 5180-5204.

38. Synthesis and characterization of carbon nanowalls on different substrates by radio frequency plasma enhanced chemical vapor deposition / K. Davami, M. Shaygan, N. Kheirabi, J. Zhao, D. A. Kovalenko, M. H. Rummeli, J. Opitz, G. Cuniberti, J. S. Lee, M. Meyyappan // Carbon. - 2014. - No. 72. - P. 372-380.

39. Uniform surface growth of copper oxide nanowires in radiofrequency plasma discharge and limiting factors / G. Filipič, O. Baranov, M. Mozetič, K. Ostrikov, U. Cvelbar // Physics of Plasmas. - 2014. - No. 21. - P. 113506.

40. Chen, F. F. Introduction to Plasma Physics and Controlled Fusion / F. F. Chen. - New York: Plenum Press. - 1984. -421 p.

41. Polyanin, A. D. Handbook of Exact Solutions for Ordinary Differential Equations / A. D. Polyanin, V. F. Zaitsev. - Boca Raton: Chapman \& Hall/CRC. 2003. - 788 p.

42. Density-functional calculation of methane adsorption on graphenes / X.P. Chen, N. Yang, J.-M. Ni, M. Cai, H.-Y. Ye, C. K. Y. Wong, S. Y. Y. Leung, T.-L. 
Ren // IEEE Transactions on Electron Devices. - 2015. - V. 36, No. 1. - P. 13661368.

43. Gallouze, M. Adsorption isotherms of $\mathrm{H}_{2}$ on defected graphene: DFT and Monte-Carlo studies / M. Gallouze, A. Kellou, M. Drir // International Journal of Hydrogen Energy. - 2016. - V. 41, No. 12. - P.5522-5530.

44. Lieberman, M. A. Principles of Plasma Discharges for Materials Processing / M. A. Lieberman, A. J. Lichtenberg. - New York: Wiley Interscience. 2005. $-757 \mathrm{p}$.

45. Anders, A. Handbook of Plasma Immersion Ion Implantation and Deposition / A. Anders. - New York: John Wiley \& Sons. - 2000. - 540 p.

46. Hydrogen adsorption on graphene: a first principles study / V. V. Ivanovskaya, A. Zobelli, D. Teillet-Billy, N. Rougeau, V. Sidis, P. R. Briddon // European Physical Journal B. - 2010. - No. 76. - P. 481-486.

47. Dean, J. A. Lange's Handbook of Chemistry / J. A. Dean, $15^{\text {th }}$ edition. New York: McGraw-Hill. - 1992. - 1292 p.

48. Structures $\mathrm{C}-\mathrm{H}$ and $\mathrm{C}-\mathrm{CH}_{3}$ bond energies at borders of polycyclic aromatic hydrocarbons / K. May, S. Dapprich, F. Furche, B. V. Unterreiner, R. Ahlrichs // Physical Chemistry Chemical Physics. - 2000. - No. 2. - P. 5084-5088.

49. Evolution of carbon film structure during its catalyst-free growth in the plasma of direct current glow discharge / V. A. Krivchenko, V. V. Dvorkin, N. N. Dzbanovsky, M. A. Timofeyev, A. S. Stepanov, A. T. Rakhimov, N. V. Suetin, O. Yu. Vilkov, L. V. Yashina // Carbon. - 2012. - No. 50. - P. 1477-1487.

50. Optimize the field emission character of a vertical few-layer graphene sheet by manipulating the morphology / Y. Zhang, J. Du, S. Tang, P. Liu, S. Deng, J. Chen, N. Xu // Nanotechnology. - 2012. - No. 23. - P. 015202.

51 . Synthesis of carbon nanosheets by inductively coupled radio-frequency plasma enhanced chemical vapor deposition / J. Wang, M. Zhu, R. A. Outlaw, X. Zhao, D. M. Manos, B. C. Holloway // Carbon. - 2004. - No. 42. - P. 2867-2872.

52. Substrate temperature effect on the growth of carbon nanowalls synthesized via microwave PECVD / S. Y. Kim, W. S. Choi, J.-H. Lee, B. Hong // Materials Research Bulletin. - 2014. - No. 58. - P. 112-116.

53. CVD growth and field emission properties of nanostructured carbon films / A. N. Obraztsov, A. P. Volkov, K. S. Nagovitsyn, K. Nishimura, K. Morisawa, Y. Nakano, A. Hiraki // Journal of Physics D. - 2002. - No. 35. - P. 357-362.

Надійшла до редакції 5.04.2021. Розглянута на редколегії 20.04.2021.

\section{Theoretical model of formation of two-dimensional nanostructures of vertical graphene under the action of plasma}

Vertically oriented graphene nanostructures have been grown for more than decade, but the mechanisms of their formation are still unclear. A multifactor model is proposed, which is verified by comparison with experimental data and describes the processes of growth of the structure of vertical graphene in plasma. The role of chemical and physical processes that cannot be directly characterized by available experimental methods, such as surface diffusion of adatoms and radicals under the action of ions, has been studied. Ion bombardment is a key factor that significantly accelerates the growth rate through the formation of surface defects and, consequently, increases the energy of surface adsorption. Hydrocarbon radicals 
formed on the substrate under the bombardment diffuse to the graphene nanosheets and serve as the main source of the construction material. Thus, the leading role in the formation of vertical graphene belongs to surface diffusion, rather than direct deposition from the gas phase. The temperature of the sample is also an important parameter, which affects the growth process according to the following mechanism: at low temperatures the adsorption from the gas phase is more intense, but the diffusion processes are slowed down; elevated temperatures have the opposite effect. The surface density of graphene nanosheets, which can be controlled at the stage of nucleation, strongly affects the height of the structure due to the redistribution of ion fluxes during the growth: as the nanosheets grow, the ion current density decreases to the side edge of the sheet and increases to the upper edge. This process leads to a decrease in the ion current density at the side edge of the nanosheet, and, as a consequence, to a change in the dependence of the graphene sheet length on time: from a saturated curve or a quasilinear time dependence to a parabolic dependence. The assumption of surface diffusion of hydrocarbon radicals as the dominant growth mechanism is consistent with existing experimental data; these results confirm the physical model, and also bring a deeper understanding of the physics of growth of vertical graphene. methods.

Key words: nanotechnology, plasma, vertical graphene, nanostructure growth

Відомості про авторів:

Баранов Олег Олегович - доктор технічних наук, професор, завідувач кафредри теоретичної механіки, машинознавства та роботомеханічних систем, Національний аерокосмічний університет ім. М. Є. Жуковського «Харківський авіаційний інститут» м. Харків, Україна; O.Baranov@khai.edu; Scopus ID: 7006294413; ORCID: 0000-0001-5356-1125

About the Authors:

Baranov Oleg Olegovich - Doctor of Technical Sciences, Professor, Head of Department of Theoretical Mechanics, Engineering and Robomechanical Systems, National Aerospace University "Kharkiv Aviation Institute", Kharkiv, Ukraine; O.Baranov@khai.edu; Scopus ID: 7006294413; ORCID: 0000-0001-5356-1125 